\title{
Field Emergence in Civil Society: A Theoretical Framework and Its Application to Community-Led Housing Organisations in England
}

\author{
Richard Lang $^{1,2}$ (D) David Mullins ${ }^{3}$
}

Published online: 31 July 2019

(C) The Author(s) 2019

\begin{abstract}
The paper aims to develop a better understanding of the evolution and structuration of contemporary civil society fields. It applies analytical elements from field theories and closely related network governance literature within a qualitative research design to explore collective action around community-led housing (CLH) in England, a label assigned to a range of alternative housing models. We argue that collective action needs to be understood as a loose coupling of earlier and younger social movements, based on their shared awareness of and willingness to address macro-level societal problems. We further identify a gradual evolution of field governance from loose covenanting between sub-fields, development of a common project, to network activation to manage significant external funding. This process has not yet led to a unified field with stable internal governance and wide external legitimacy on the national level. However, an embryonic field structure and permeable boundaries provide CLH actors multiple hybrid identities and strategic positioning opportunities in adjacent fields. We believe that our strategic
\end{abstract}

Richard Lang

richard.lang@jku.at

David Mullins

d.w.mullins@bham.ac.uk

1 Institute of Innovation Management, Johannes Kepler University Linz, Altenbergerstrasse 69, 4040 Linz, Austria

2 Housing and Communities Research Group, Centre on Household Assets and Savings Management, School of Social Policy, University of Birmingham, Edgbaston, Birmingham B15 2TT, UK

3 School of Social Policy, Housing and Communities Research Group, University of Birmingham, Birmingham B15 2TT, UK field perspective can shed light on the nature of collective action in other parts of the civil society.

Keywords Community-led housing · Collaborative housing · Social movements · Network governance $\cdot$ Civil society $\cdot$ Field analysis

\section{Introduction}

Civil society participation in housing has received growing interest in many countries from activists and academics alike over the past 10 years (id22 2012; Kehl and Then 2013; Mullins and Moore 2018). The term "collaborative housing" is gaining ground as a generic descriptor for an international housing phenomenon with a strong social dimension. It highlights residents' self-organisation, intentional community building but also partnerships between local grass-roots organisations and larger nonprofits as well as state and market actors (Fromm 2012; Lang et al. 2018).

Interest in collaborative housing is partly related to demographic change and the search for alternative forms of living among older people (Jones 2017). Further, higher costs of living drive people of different age into collective action around housing (Jezierska and Polanska 2017). Collaborative housing also represents a lifestyle linked to sustainable living, the sharing economy, self-determination in housing choice and enjoying community in the immediate neighbourhood which, for instance, appeals to younger families (Ruiu 2014; Huber 2017). At the same time, collaborative housing models can run the risk of becoming inward-looking and self-selective living arrangements in the long term (Brandsen and Helderman 2012). 
The importance of these factors varies between territorial contexts, and we also find a variety of context-specific collaborative housing models, such as co-housing, residents' co-operatives, self-help and community self-build initiatives, ecological housing communities or community land trusts (CLTs). Furthermore, there is the temptation to assume that the recent surge of collaborative housing initiatives coincided with the financial crisis in 2008 when market and state failure left spaces for potential civil society action in housing in cities but also rural areas. Indeed, some collaborative housing actors have only recently emerged and expanded, for instance CLTs, which spread through increasing internationalisation of social movements. However, other collaborative housing models have been around for much longer (e.g. resident-led cooperatives) and have been stimulated by earlier opportunities and trigger events such as public funding (Mullins and Moore 2018).

This paper aims to explore the factors influencing the recent re-emergence of organised collective action around the theme of collaborative housing. The resurgence of collaborative housing is still a little researched phenomenon and provides an interesting research topic for civil society studies. In our research endeavour, we draw on insights from field theory and contribute to the literature on field emergence and institutionalisation in the civil society sphere, and especially in housing practice. Previous field analyses on housing have mainly focused on more established non-profit housing fields in the UK and Ireland stimulated by public grants (Mullins and Riseborough 1997; Mullins et al. 2001) and in the USA stimulated by the Low-Income Tax Credit model (Guthrie and McQuarrie 2008; McQuarrie and Krumholz 2011). However, many organisations involved in collaborative housing have a strong grass-roots character and do not align themselves with the formal non-profit sector (such as housing associations). The emergent character and institutionalised nature of collaborative housing provides an important contrast to earlier non-profit studies and thus an important addition to the fields literature.

Our analysis shows that it is fruitful to draw on recent literature on urban social movements (Domaradzka 2018) which has strong resonance for collaborative housing. Fligstein and McAdam's work on Strategic Action Fields, for instance, has attracted recent interest among scholars concerned with social movements (Pettinicchio 2013; Domaradzka and Wijkström 2016) and is thus also appealing to studies dealing with parts of the non-profit sector, such as grass-roots action. Further insights are generated by work on the institutionalisation of civil society fields (Nicholls 2010a, b; Nicholls and Teasdale 2017). In line with Barman (2016) and Krause (2018), we believe that different field traditions (Bourdieusian, New Institutionalist and Strategic Action Fields) can complement each other in the analysis of particular fields.

The empirical analysis in this paper explores a particular national field of collaborative housing practice with a pronounced configuration of actor groups. In England, the label community-led housing (CLH) has been assigned to a range of alternative housing models that have sprung out of different social movements (Heywood 2016). Some of them have been around for a long time (e.g. mutuals and co-operatives, self-help housing), others have more recently emerged including CLTs, co-housing, community self-build housing. Although there is no commonly agreed definition of CLH, these organisational forms are characterised to varying degrees by citizen participation in governance and day-to-day management of housing construction, renovation and reuse of existing homes, longterm affordability of housing and (local) community orientation (see also Fig. 2).

CLH might be seen as a unified response to the highly dysfunctional and crisis-ridden contemporary housing system in England, heightened by the aftermath of the 2008 financial crisis. However, it has important historical antecedents and within this "new" housing movement, we find significant internal diversity and a variety of terminologies and labels that reflect the history of specific grass-roots niches and the umbrella organisations that evolved to support them (Heywood 2016).

The detailed analysis of a collaborative housing field in one particular country, including specific historical and cultural context and structural factors, reflects the comprehensive research tradition of Bourdieu (Benson 2006; Krause 2018). However, we also acknowledge the importance of comparative field analyses which help to identify shared patterns and differences across territorial contexts (Krause 2018). Our analysis of field emergence will be guided by specific categories identified from the literature which should facilitate international comparisons of similar fields.

Thus, the next section identifies and discusses key dimensions of field theories that deal with field emergence. After introducing the methodology of this study, these identified dimensions will guide the historically embedded analysis of CLH in England, followed by a discussion of results. Finally, conclusions will outline the main implications of our study for field research in the civil society and housing sector. 


\section{Field Emergence and Evolution: A Theoretical Framework}

Field theory has become a common analytical approach for sociological inquiry into the civil society and non-profit sector (Barman 2016). What all three major field approaches (the Bourdieusian, New Institutionalist and Strategic Action Fields perspectives) have in common is the relational understanding of a field, i.e. that actors and their ideas and practices are either directly positioned to each other, or oriented towards a shared stake (Emirbayer and Johnson 2008; Macmillan 2013; Swartz 2014). Building on this fundamental understanding, in this paper, the term field is used for a meso-level social order where (collective and individual) actors "consider each other relevant with regard to specific professional or specialized practices" (Krause 2018, p. 5), which in our case is defined as collaborative housing.

Field-theoretical traditions differ in their assumption what constitutes a field. According to Bourdieu, the field refers to an inherently contested space where individuals compete over resources to gain positioning advantage relative to each other (Bourdieu 1990, 1991; Bourdieu and Wacquant 1992). In contrast, new institutionalist scholars use the notion of fields when conceptualising the role of conformity in organisational life which refers to the adaption of behaviours and practices by following successful organisational examples (Scott and Meyer 1983; DiMaggio and Powell 1983; Scott 1995). Such conformity plays out in already existing fields where relevant actors "constitute recognized areas of institutional life [...] that produce similar services or products" (DiMaggio and Powell 1983, p. 148). The Strategic Action Field (SAF) framework (Fligstein and McAdam 2011, 2012) claims to synthesise the Bourdieusian and new institutionalist approaches and to address their perceived weakness of passive conception of actors by stressing the role of agency and field dynamics, such as formation or crisis (Swartz 2014). Although we need to take account of the criticism regarding the SAF approach as a comprehensive theory of society (Fuchs 2014), its relevance and strength for our study lie in analytical elements that deal with strategic agency, coalition building and shared meaning among actors in field formation (Fligstein and McAdam 2012). In this endeavour, we are building on existing field research on civil society organisations (Macmillan et al. 2013; McInerney 2015) and are particularly interested in understanding "the ability of actors to join others together to pursue a shared goal" (Barman 2016, p. 451).
Another recent strand of theory builds on the neo-institutional approach to consider processes of institutionalisation within emerging civil society fields and includes a greater focus on agency. Nicholls (2010a, b) draws on Kuhn's concept of paradigm shift to explore field formation and legitimation in the social enterprise field in England which he describes as "pre-paradigmatic" (Nicholls 2010a, p. 611). At this stage of field development, Nicholls observes contests for control of legitimation discourses and paradigmatic dominance. He describes an interplay between actors and structures involving "reflexive isomorphism" (Nicholls 2010a, p. 614) in which resourcebased pressures force compliance with existing normative frames of reference through a mix of regulative, normative and cognitive adaptation. Meanwhile, agency is asserted to re-socialise legitimation processes.

The integration of different field traditions leads to the following analytical dimensions that help to study the role of strategic actors in the formation process of CLH in England.

(1) Opportunities in the Broader Field Environment: In line with New Institutionalism, the SAF approach highlights that events in the field environment deserve attention as they provide the initial opportunity for contestation (Barman 2016). Nicholls and Teasdale (2017) concur with SAF writers that institutional change or paradigm shift within a field requires an external shock. Thus, the state often creates the conditions for new fields by introducing legislative changes and provision of resources which organisations see as new opportunities (for example, the grants provided by the Co-operative Housing Agency in England in the late 1970s). Guthrie and McQuarrie (2008), for instance, show how the introduction of the Low-Income Housing Tax Credit (LIHTC) in the Tax Reform Act of 1986 in the USA led to a reorganisation of actor relationships in some cities and to the emergence of a new organisational field. They conclude that the institutional context conditions matter how the policy change precisely affects field formation in a particular place. Similarly, "empty" social spaces can be the result of boundary changes of existing non-profit fields but also the state field (Gorski 2012). When established actors cede their field positions, actors from adjacent fields or newly emerging actors are likely to move into empty field spaces, for instance, because these promise to provide new niches or opportunities. Mullins et al. (2001) provide evidence how the emergence of state-funding resources was linked to the expansions of field boundaries of the non-profit housing sector in Ireland and its actor configuration. The crystallisation of a new field can also be traced back to the crisis of 
an existing field where the rules that governed interaction no longer work, and actors are consequently looking for a new consensus to consolidate the field. In her study on the lesbian/gay movement in San Francisco in the 1970s, Armstrong (2005) suggests that the more intense such a field crisis is, the less likely the old order will be reestablished and the more contentious the process of achieving field settlement will be. Echoing the findings of Armstrong, recent studies of housing movements in Budapest and Bucharest (Domaradzka and Wijkström 2016; Florea et al. 2018) suggest that we need to engage in a historically informed analysis to identify both structural and contingent factors in the external environment as triggers for field formation in civil society around issues of housing (e.g. the financial crisis of 2008 and global dynamics of commodification in housing).

(2) The Use of "Social Skill": "Socially skilled" actors may play a crucial role in emerging fields by recognising, shaping and enacting new entrepreneurial opportunities. These institutional entrepreneurs are able to transcend narrow group interests and appeal to common interests and build coalitions so that a new field can actually emerge (Fligstein and McAdam 2011). An important part of this entrepreneurial activity is to provide practical solutions to local problems which shows how things can be done in a different way (Domaradzka and Wijkström 2016). McQuarrie and Krumholz (2011) highlight the role of mediating organisations as an institutionalised form of social skill which is critical to the governance of local housing and community development fields in the USA.

The literature on network management and governance provides further insights that can enhance our understanding of social skill. Building on the policy networks literature (Marsh and Rhodes 1992), the "Governance Club" research programme at Erasmus University Rotterdam developed concepts and tools of network management with strategic, managerial and behavioural dimensions (Koppenjan and Klijn 2004) that have been applied to analyse network governance in housing and urban regeneration (Van Bortel and Mullins 2009). Further studies have highlighted the role of local organisational innovation driven by the practical skills and experimentation of institutional entrepreneurs to bridge organisational boundaries (McQuarrie and Krumholz 2011). Finnemore and Sikkink (1998) have highlighted the role of organisational platforms as network hubs and stabilisers of collective action. In the context of social movements, platforms might not have the characteristics of a formal organisation and thus membership depends on mutual recognition (Ahrne and Brunsson 2011). LIHTC provides another housing example where actor-driven governance innovations on the ground successfully established a new field among nonprofit housing actors which has produced nearly 3 million affordable homes in the USA (Smith 2010). An important tool used by institutional entrepreneurs in fields is the framing of issues and compromise identities to which other field actors can agree. Thus, frames can unify heterogeneous actors and their agendas in fields (e.g. of grass-roots and more formalised non-profit actors) and successfully intermediate between an opportunity in the external environment and collective action (Snow and Benford 1992; Diani et al. 2018). This also involves linking local issues with existing international frames and related actor networks (Domaradzka and Wijkström 2016). However, given their own resource limitations, actors often face strategic decisions in the field formation process to push either their own or wider group interests (Fligstein and McAdam 2011). Armstrong (2005) further suggests that the institutionalisation of a new field logic depends heavily upon timing. When a moment of opportunity arises, entrepreneurs need to come up with a viable project and the right frames in the right place. For our empirical analysis in this paper, we need to explore the playing out of tensions between field and sub-field actor interests and the effectiveness of reframing in stimulating a moment of opportunity (e.g. the provision of external funding).

(3) Field Autonomy: When fields emerge, they become more autonomous, i.e. actors are guided by their own field norms and formal regulations and develop field-specific capital and their own field logic (Bourdieu 1995; Gorski 2012). It is often assumed that autonomy is necessary for a field to help fulfil its specific purpose, but at the same time, autonomy can lead to a degree of closure (Krause 2018). Furthermore, there is not one form of field autonomy but it needs to be seen as relative under particular circumstances. For instance, Bourdieu's analysis of the emergence of the literary field in the nineteenth century in France shows that literary production, of course, has existed before-but it was subsumed under a different field logic, such as that of courts or publishers (Bourdieu 1995, Gorski 2012). Thus, analysis of field autonomy concerns the position of a specific field within "the overall architecture of fields that it is embedded in" (Krause 2018, p. 10). In this respect, Fligstein and McAdam's (2011, p. 3) notion of "Russian dolls" is a fruitful metaphor and helps to conceptualise CLH as a housing field where actors are embedded in larger and smaller SAFs at the same time (Barman 2016). Similarly, Nicholls and Teasdale (2017) reinforce the need to focus on multiple levels that affect micro-level field actors and on the boundaries between emerging fields and 
more institutionalised and powerful neighbouring fields. The authors reject the possibility that paradigm shift might occur at the micro-level in isolation from change at the macro- and meso-levels. Thus, despite an apparent flurry of activity at the micro-level around social enterprise practice, they observed little cognitive change, since this would have required "a shift away from the (macro-level) neo-liberal belief that markets are the best way to organise and govern society" (Nicholls and Teasdale 2017, p. 338).

In the light of this, our empirical field analysis needs to explore the extent and nature of links between CLH and adjacent housing-related fields. This involves an analysis of resource transfers between fields and how these help in advancing the relative autonomy of the CLH field (Ferguson 1998). However, more links do not necessarily mean less autonomy, as increased resource exchanges with one adjacent field could enable the emancipation from another field. A good example is the emergence of journalism as a field which was triggered by growing dependency on markets which eventually enabled journalists to become relatively autonomous from political patronage (Chalaby 1998; Krause 2018).

(4) Field Structure: In the Bourdieusian tradition, analysis of this dimension fundamentally relates to the question how actors with specific backgrounds occupy and hold positions in a field at a given point in time. This leads to an analysis of the degree of hierarchy (i.e. power relations) and orthodoxy in a particular field (Gorski 2012). Orthodoxy refers to the degree of consensus and acceptance of the rules of the game among actors in a field. However, consensus might not necessarily be achieved through strong hierarchy (Krause 2018). In their SAF theory, Fligstein and McAdam $(2011,2012)$ distinguish between a powerful actor group of "incumbents" who benefit from the existing rules of the game and "challengers" who are not favoured by the status quo and thus are more likely to mobilise coalitions to enact change (see also Gamson 1975).

However, the composition and the roles of relevant actor groups might not be so clear-cut in emergent fields (Swartz 2014). Emerging fields may instead constitute unorganised social spaces where shared understanding of the purpose and agreed rules that govern their interaction do not yet exist or are constantly challenged among actors. Furthermore, the situation may be quite fluid with new actors frequently appearing but also leaving the field. Recent accounts of urban social movements mobilising around housing, such as "Right to the City", indeed paint fields as unstructured social spaces of contentious action and different struggles. Actor groups in these fields have various agendas and come from different ideological and social backgrounds. They often only build temporary coalitions when it serves their strategic interest (Diani et al. 2018; Florea et al. 2018). Depending on the territorial context, these can involve non-profit housing association, grassroots neighbourhood organisations and tenant initiatives (Domaradzka 2018)

For the stability of a field, the key question will be whether or not "governance units" become organised more hierarchically or co-operatively (Fligstein and McAdam 2011). This is influenced by the power of actors and their resource endowment. Nicholls (2010b) draws attention to the need to explore very specific processes in field institutionalisation such as regulation and reporting regimes whereby the legitimacy of new fields is contested.

Three specific concepts from the network management literature were found particularly useful in interpreting the patterns of inter-organisational relations that emerged in the CLH field. First, borrowing from Ostrom (1980), Klijn and Teisman (1997, p. 106) introduce the idea of "covenanting" as a social learning process whereby actors explore similarities and differences in their perceptions of what needs to be done, with what resources and under what conditions. Covenanting does not require complete agreement on all goals, merely instrumental agreement on parts of a package of actions that are in the interests of each networked actor.

Second, Klijn and Tiesman (1997) further discuss how the ability of networks to act collectively can be enhanced by "reframing actor perceptions" to decide which network games they wish to participate in and which goals and values matter. This may involve the building of shared projects and co-ordinated actions, for example, to attract external resources to support network activities. Third, "activation" refers to the selection of specific network actors to participate in "network games" and the definition of the roles they are to play within those games. This may include existing network actors expanding or changing their roles, bringing new actors into the network to provide necessary resources and indeed de-activation of existing network members who may be blocking proposed games. Later in this paper, we relate these three concepts to the timeline of events in the CLH field formation project.

\section{Methodology}

Collaborative housing fields, including CLH in England, are still an under-researched phenomenon (Lang et al. 2018). Thus, a qualitative research strategy was applied to 
reconstruct the historical trajectory and concrete configuration of the CLH field (Sayer 1992; Yin 2009). Furthermore, we applied an abductive approach, moving from initial hypothesis testing, through more inductive case studies and observation to abduction to develop a deeper understanding of the emergence of CLH and relate this to field theory.

The paper draws on the data reservoir of a larger project on collaborative housing by the authors. The research reported in this paper involved secondary data analysis (e.g. government papers and Internet sources on CLH) and two waves of field work in 2013/14 and 2015/16. This generated a total evidence base of 60 semi-structured qualitative interviews with housing experts and representatives of CLH umbrellas and case organisations from across England. The case studies of organisations were selected from the main housing forms that CLH brings together (see also Fig. 2) and contrasted different actor perspectives. Particularly relevant for our CLH field analysis were interviews with management executives and key external stakeholders, such as representatives of larger nonprofit housing providers, government bodies and charitable foundations who together constitute the main sources of external support for the field. These interviews helped to reconstruct interactions and resource flows among field actors, whereby interviewees were encouraged to provide concrete examples of networking.

Interviews were taped and transcribed, and complemented by analysis of archival data (including Internet and media sources) as well as field notes from participatory observations of meetings at the level of CLH umbrella bodies, such as the Community-Led Housing Alliance (CLHA), the Confederation of Co-operative Housing $(\mathrm{CCH})$ and self-help-housing.org (SHHO). Qualitative content analysis (Mayring 2010) helped to structure the empirical material from interview transcripts, observation protocols and documents in accordance with the field analytical dimensions outlined in the previous section, i.e. emblematic events in the broader field environment, identification of key individual and collective actors involved in CLH and examples of applied "social skill" by these actors. Tables 2 and 3 in the Appendix present a list of key empirical data sources that informed the analysis in this paper. Our understanding has been continuously updated between 2016 and 2019 through active engagement with developments in the field including engagement by one author in a regional enabling hub and a national partner in CLH (UK Cohousing Trust).

\section{Empirical Findings: Community-Led Housing (CLH) as an Emergent Strategic Action Field}

This section explores evidence on the emergence of $\mathrm{CLH}^{1}$ as a field in England. It proceeds by reviewing developments in the broader field environment, continues by considering the use of "social skill" by field actors and then discusses field autonomy and finally the structure of the CLH field.

(1) Developments in the Broader Field Environment of CLH

First, we briefly engage in a historically informed analysis to identify both structural and contingent factors in the broader institutional environment as triggers for the formation of CLH as a field in England.

Figure 1 considers some of the long-term external shocks nationally and internationally that have stimulated the component movements comprising CLH over the past century.

One temptation is to limit the explanation of the emergence of CLH as a field to the immediately observable exogenous shock of the financial crisis in 2008 and recent state action (Mullins and Moore 2018). This might include the election of a Coalition Government in 2010 followed by their Big Society and Localism Agenda which led to small-scale state funding for CLH including a $£ 50$ million self-help housing initiative. More recently, the exacerbation of the rural homes crisis brought about by second home ownership in the south-west of England led to further state support and up to $£ 300$ million funding for CLH. These recent developments may contribute to the ultimate creation of CLH as a new strategic space for civil society organisations in housing. However, it also needed actors from existing, adjacent fields to populate this emergent space and to advance legitimating discourses and logics in a contest to develop a more recognisable field.

The principal ideas of CLH were not invented in the early 2000s but can be traced back to the first half of the nineteenth century, articulated by the Rochdale co-operative movement. With a longstanding tradition in England, co-operative and mutual housing had become an established field on its own (Birchall 1992; CCMH 2009; Rowlands 2009). The co-operative movement epitomised by the Rochdale pioneers and the first terminating building societies can lay claim to have been the forebears of CLH. Early drivers for co-operative housing came from the spread of utopian ideas responding to urbanisation and poor housing thrown up in the industrial revolution. This

\footnotetext{
${ }^{1}$ Community-led housing (CLH) is used throughout this section to reflect the more common use of this term than the term collaborative housing in England.
} 
Fig. 1 Exogenous shockslong-term and short-term drivers. Source: Authors

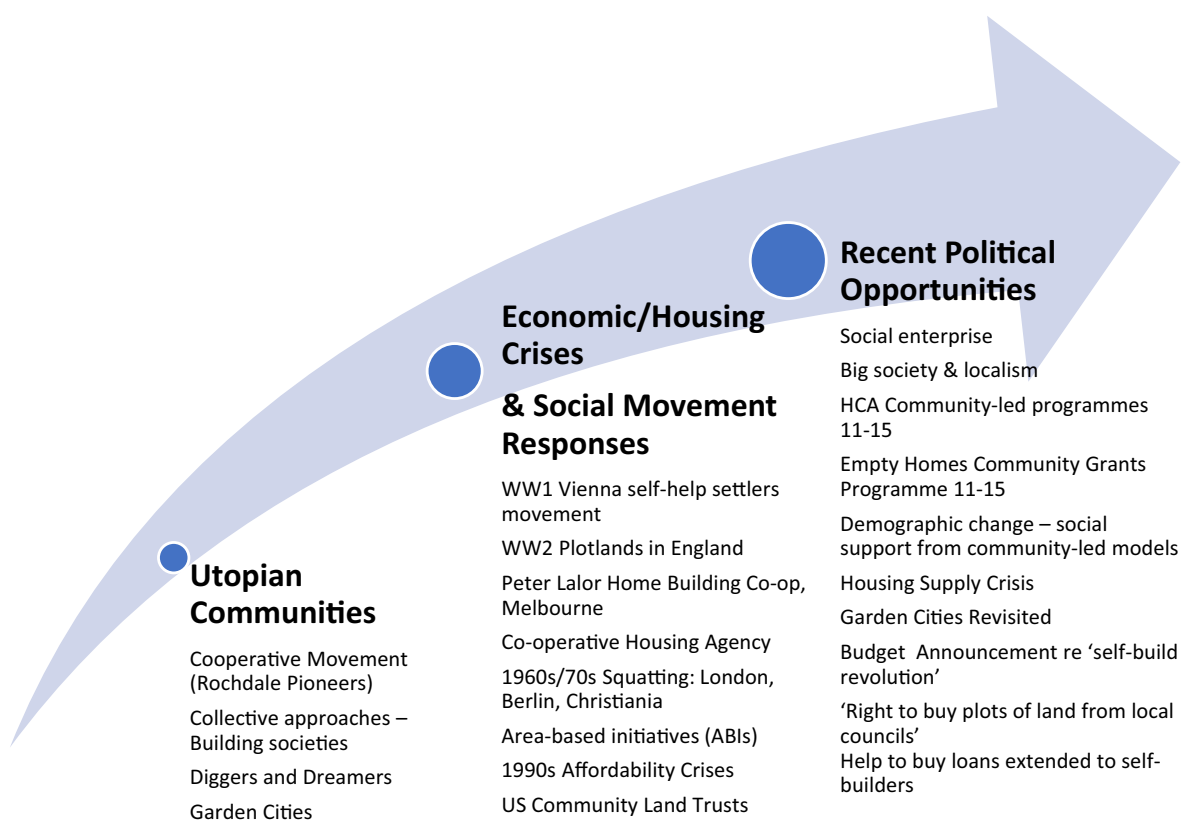

included the Garden City Movement and Ebenezer Howard's collective land ownership model which could lay claim to being the first CLT in England (Howard 1898). This was later picked up in CLT understandings of "common ground" (Davis 2002). The co-operative principles (ICA 2015) represent an internationally shared understanding and identity among its field actors, and specific governance units were developed in the co-operative housing field in the 1970s which still exist today. Part of this is a central governance body (Confederation of Cooperative Housing- $\mathrm{CCH}$ ) and a network of regional supporting secondary co-operatives in some areas of England (e.g. Birmingham, Liverpool and the London area). Despite a more elaborate higher level structure linking the field to government resources, the Co-operative Housing Agency was short-lived, lasting from 1976 to 1979, the peak period for government funding for new build co-operatives (Murie 2008).

Despite these ambitions, from 1988 on, the focus of government funds shifted to mixed funded (public and private) projects by larger non-profit housing associations (Murie 2008) and funding was increasingly hard to secure for housing co-operatives. The diminished legitimacy of co-operatives within the housing field limited opportunities for serious attempts of new co-operative housing developments until 2010. Still, co-operative and mutual housing organisations-of which there are now 836 across the UK-are comparatively well-established actors within the CLH field, managing a stock of around 169,000 units, with
91\% of co-operatives based in England (Heywood 2016). Another strategic actor which re-entered the CLH field in the first decade of the 2000s is self-help housing (Mullins 2018). It can be seen as distinct from but overlapping with formal co-operative housing models and has its roots in an informal squatting movement for local authority-acquired housing, left empty following the IMF financial crisis of the mid-1970s. Since then, a majority of housing co-operatives have been incorporated within the regulatory framework of the social housing sector for receiving public funding (Rowlands 2009).

Recent developments in the field environment have drawn new actors into the CLH field (see Fig. 2). These emerged as responses to new external drivers, such as the need for longer term affordability in high-cost rural and urban areas (CLTs), shared housing within intentional communities (co-housing) and local action to bring empty homes into use (self-help housing). Their housing aims and strategies sometimes appear more palatable with dominant liberal regime practices and current political priorities in English housing. In contrast to co-operatives, this alignment with the macro-level political economic regime $(\mathrm{Ni}$ cholls and Teasdale 2017) enhances their legitimacy as indicated for instance by the introduction of a national selfbuild register and pressure on local authorities to release land for (community) self-build.

An important momentum for the emergence of CLH as a field in England, bringing together the older and more recent CLH movements, has come in the early 2000s from 
Fig. 2 Overlapping aims and models. Source: Authors

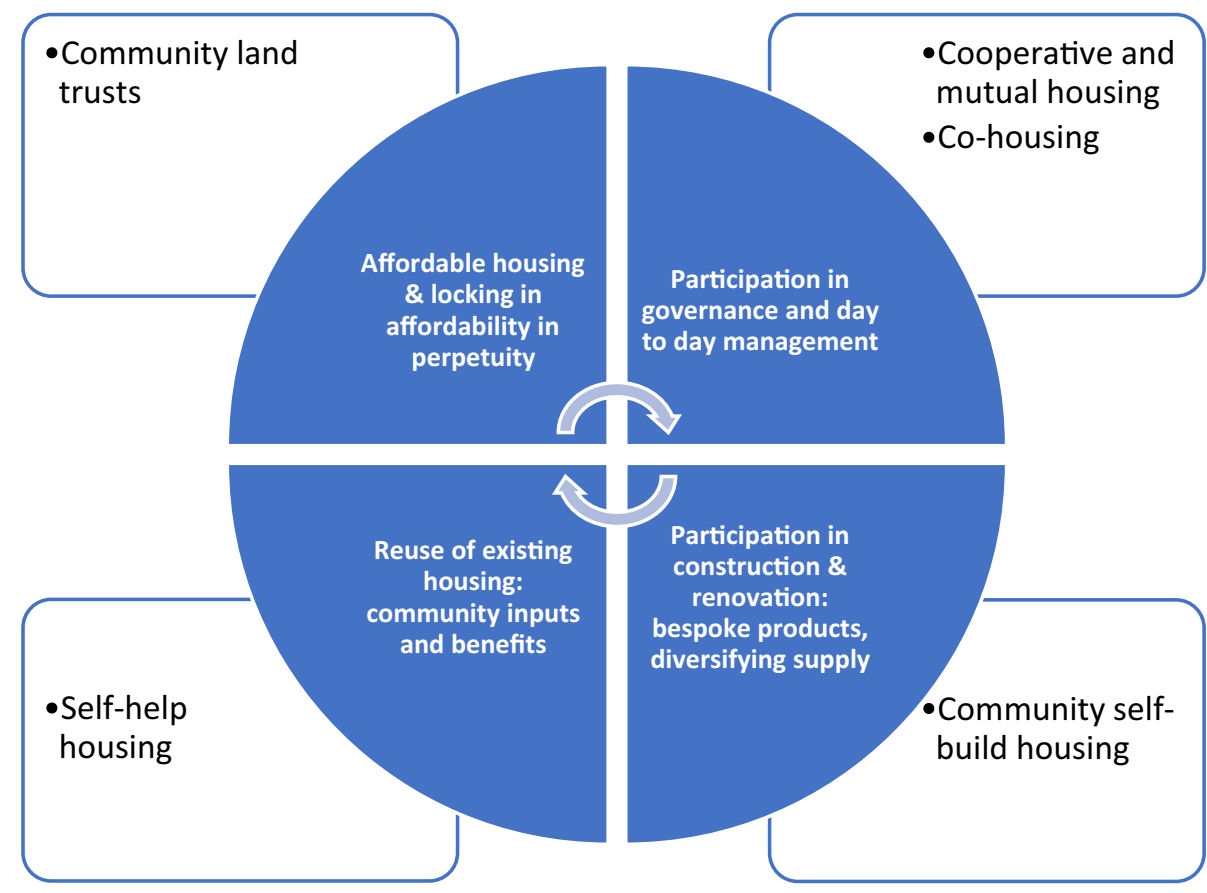

perceived failures of mainstream social housing to meet the needs and aspirations of residents. The field of non-profit housing associations in England had seen remarkable growth and stabilisation over the last 30 years (Purkis 2010; Mullins 2016). Today, commercial large housing associations that account for most of the stock have clearly moved away from their original community focus. Nevertheless, there are signals of field fragmentation with a small, more traditional value-based part of housing associations that is less comfortable with state policies and large-scale commercialism. It acts as partners of grassroots housing organisations and is thus also aligned to the CLH field.

(2) The Use of "Social Skill"

There are examples of CLH actors who have been effective in reading the environment, making connections, framing action and mobilising people. However, this has usually operated in specific parts of the CLH field. Taking the case of self-help housing, "social skill" has been deployed to knit together fragmented actors in different arenas (Koppenjan and Klijn 2004) under a common platform (self-help-housing.org-SHHO)_forging a consciousness of field by both participants and external actors, to mobilise quite significant state support. SHHO developed a discourse to legitimate self-help housing as a way to address multiple social problems (e.g. empty homes, homelessness, employment and training, and fear of crime problems) and to present itself as a solution relevant to contemporary policy and political streams (Cohen et al. 1972; Mullins 2018). SHHO was able to demonstrate the relevance of the solutions provided by self-help housing to a series of "wicked problems" including the Coalition Government's (2010-2015) need to give practical substance to political ideas of a "big society" and "localism". The role played by SHHO is resonant of the self-reflexivity depicted by Nicholls (2010a). This micro-level actor attempted to build a distinct logic of "self-help housing" by working on micro-structures of legitimation and contrasting this with the abandonment of the niche by larger established housing associations (Mullins 2016).

Once the prospect of state funding through the Empty Homes Community Grants Programme was opened, SHHO undertook a very specific programme of work to demonstrate and build capacity of potential participants. It organised an "expressions of interest" call and support for bid writing and delivery through online information and peer networking events. This rapidly led to a variety of organisation types to (re)define themselves as part of the self-help housing movement and doubled the number of active local projects over a few years.

SHHO actively brokered links between the self-help and other CLH actors and was an active player in the Mutual Housing Group (MHG) and Community-Led Housing Alliance (CLHA) to promote CLH with government (BSHF 2014a, b). The impact of this work in forging common cause was apparent in the National CLT Network (NCLTN) 2015 Election Manifesto which made the case 
for $£ 52$ million further public funding for empty homes projects (NCLTN 2014). This partly reflected the dual identity of several projects (such as Middlesbrough CLT and Granby Four Streets CLT) as both CLT and self-help housing projects, reflecting the overlapping purposes of CLH groups (see Fig. 2).

Although SHHO as well as NCLTN and CCH leadership were very strong collaborators in the MHG and CLHA, they did not at that time use "social skill" to pursue the construction of an overarching field identity. We might question whether the above examples within specific parts of the CLH field fully meet the definition of "social skill" as a "cognitive capacity for reading people and environments" for CLH as an overarching field-building project (Fligstein and McAdam 2011, p. 7). However, they do surely provide examples of framing specific lines of action and mobilising people and groups to significantly expand local CLH project activity.

(3) Field Autonomy

To explore the autonomy of the CLH field, we need to look at the extent and nature of links between CLH and adjacent fields, including resource transfers. In terms of broader national housing fields, the emergence of CLH can be related to its boundaries with all three mainstream housing tenures in England. It seeks to provide alternatives by providing greater space for individuals and communities to influence their housing (see Fig. 2). In relation to the home ownership field, CLH aims to challenge the status quo by creating additional choice, improving aspirations and therefore empowering consumers and communities (BSHF 2014a). Thus, for instance, CLTs focus on affordability in perpetuity, while community self-build focuses on increased control in the construction process for individual and collective ownership of assets. Meanwhile, selfhelp housing operates more on the boundary of the private rental housing field, bringing unused assets back to provide alternatives to or partnerships with privately owned rental housing. Furthermore, in relation to the field of social rented housing, CLH can be seen as a way of returning to some of the original purposes and visions of social housing that had been lost as most non-profit housing associations had scaled up, become more commercial and moved away from the "community space" (Mullins 2016).

The most significant resource streams into CLH come from the state field and from charitable foundations. Funding for CLH has usually been secured through mainstream public housing institutions such as the Homes and Communities Agency (HCA 2011), now known as Homes England, the Ministry of Housing, Communities and Local Government (MHCLG) (until 2018 known as Department for Communities and Local Government-DCLG) and local authorities. An interesting departure from this public funding practice was the Empty Homes Community Grants Programme which directed $£ 50$ million to self-help housing between 2012 and 2015. It was channelled by MHCLG through an intermediary called Tribal with a mandate to allocate funds to civil society organisations but with no specific housing expertise. The most important example of state funding for CLH since the 1970s is the Community Housing Fund which in 2016 initially allocated $£ 60$ million funding focused on CLTs in areas with large numbers of second homes. Later the government made available an additional $£ 163$ million across England up to 2020 through the Community Housing Fund (Homes England 2018).

The CLH field is also connected to the wider civil society field and its sub-fields that span well beyond housing. Notably, we found broader based intermediaries and governance units within civil society which had become interested in CLH because of its potential to contribute to scaling up innovations across a whole range of community asset areas, such as energy, food, transport as well as housing. Large national civil society support and funding organisations with a wider remit than housingsuch as Nationwide Foundation and Power to Changehave launched dedicated programmes for CLH. This indicates a growing recognition of the potential of CLH to influence a wider range of adjacent fields.

\section{(4) Field Structure}

This section looks at the configuration of actors in the CLH field and to what extent field formation was constructing a distinct regulatory space (Nicholls 2010b). Table 1 shows the different governance units that have emerged within the CLH field and the three stages of enhanced network co-ordination that have occurred since 2010 .

The first phase (2010-2014) saw the blossoming of umbrella groups to promote the development of CLH through a loose alliance structure, with the bulk of the limited resources and activity being focused on the individual actors' umbrella bodies. The Mutual Housing Group (MHG) which emerged following the $\mathrm{CCH}$ Mutual Housing Commission in 2009 was an important early effort at field co-ordination but was unstaffed, simply convened periodic co-ordination meetings between 2010 and 2014.

Drawing on the network management concepts discussed earlier, we now interpret this period as one of "covenanting" in which the main existing actors represented by the five umbrellas began to align their goals and identified actions that have some benefits for each actor. The most significant outcome of this phase was in identifying common support needs to promote CLH options and communicate them to potential participants at the local level. At this time, there was little enthusiasm for merging identities into a single CLH body but steps were made to 
Table 1 Forming umbrellas and building alliances. Source: Authors

\begin{tabular}{|c|c|c|c|}
\hline & \multicolumn{3}{|l|}{ Phase } \\
\hline & 2010-2014 & 2014-2018 & (2018-date) \\
\hline $\begin{array}{l}\text { Governance } \\
\text { unit }\end{array}$ & Mutual Housing Group (MHG) & $\begin{array}{l}\text { Community-Led Housing Alliance } \\
\text { (CLHA) }\end{array}$ & $\begin{array}{l}\text { Community Led Homes-Joint Venture } \\
\text { Collaboration Agreement (CLH) }\end{array}$ \\
\hline $\begin{array}{l}\text { Network } \\
\text { management } \\
\text { theme }\end{array}$ & $\begin{array}{l}\text { Covenanting: loose co- } \\
\text { ordination of existing } \\
\text { networks to explore } \\
\text { opportunities for goal } \\
\text { convergence }\end{array}$ & $\begin{array}{l}\text { Reframing: emergence of shared project } \\
\text { and co-ordinated action to secure } \\
\text { external resources }\end{array}$ & $\begin{array}{l}\text { Activation: network constitution and } \\
\text { redefining tasks of participants' shared } \\
\text { national infrastructure and regional structure } \\
\text { to deliver Community Housing Fund } \\
\text { programme }\end{array}$ \\
\hline $\begin{array}{l}\text { Key empirical } \\
\text { evidence }\end{array}$ & $\begin{array}{l}\text { - Loose alliance of five existing } \\
\text { networks } \\
\text { - Sharing practice and } \\
\text { experience } \\
\text { - Jointly promoting sectors and } \\
\text { producing options maps for } \\
\text { emerging groups } \\
\text { - Occupying and shaping spaces } \\
\text { once filled by housing } \\
\text { associations } \\
\text { - Space in which community-led } \\
\text { groups can grow } \\
\text { - Scope for broader alliances } \\
\text { with developers, local } \\
\text { authorities and housing } \\
\text { associations }\end{array}$ & $\begin{array}{l}\text { - Increasing collaboration between } \\
\text { umbrellas through a jointly owned } \\
\text { project managed by BSHF (now Habitat } \\
\text { International) } \\
\text { - Collective lobbying resulted in } \\
\text { Community Housing Fund and growing } \\
\text { support from foundations } \\
\text { - Aims emerge to develop a national } \\
\text { network of hubs to promote to support } \\
\text { all forms of CLH at the regional/sub- } \\
\text { regional level }\end{array}$ & $\begin{array}{l}\text { - Delivery of Community Housing Fund and } \\
\text { foundation programmes lead to a national } \\
\text { co-ordination infrastructure linked to } \\
\text { regional delivery hubs } \\
\text { - Existing umbrellas take responsibility for } \\
\text { different aspects of infrastructure support } \\
\text { across the whole CLH field } \\
\text { - Growing number of regional enabler hubs } \\
\text { (Bristol, Leeds, Birmingham, Tees Valley, } \\
\text { etc.) } \\
\text { - National Advice Centre and website http:// } \\
\text { www.communityledhomes.org.uk } \\
\text { - Training and accreditation for advisers } \\
\text { - Small grants programme }\end{array}$ \\
\hline
\end{tabular}

find an external partner with the resources and capabilities to provide common support resources.

The second phase ("reframing") began in 2014 with the incorporation of a new actor into the network (BSHF-now "World Habitat") who convened a landmark consultation event at Windsor Castle "scaling up community housing solutions" and galvanised a new joint project "Community-Led Housing Alliance (CLHA)". Figure 2, used at that event, illustrates the emerging shared understanding of the field and the overlapping aims and models that the different CLH actors represented.

CLHA had a wider membership than the MHG with, for example, other charitable foundations and universities. Furthermore, BSHF actively sought to build a wider network of support for the movement including promotion with central government and provided a guidance and advice service for over 40 local authorities. Alongside improved sector data (Heywood 2016), the BSHF project attracted financial support from another foundation, Nationwide Foundation, who provided grant funding of $£ 169,000$ to strengthen actor links within the CLHA.
According to the Nationwide website, "Another success was the establishment of 'community-led housing' as a term...widely used across the media, housing sector and beyond". 2

In this phase of "reframing", joint action by alliance members, including a funding proposal to government, led to the major breakthrough on state funding when the Community Housing Fund was first announced by the Chancellor of the Exchequer in November 2016. Jointly organised activities increased, for example, local workshops co-organised by the CLT and Co-housing umbrellas, and the first ever national community-led housing conference held in London in November 2017.

The third ("activiaton") phase, from 2018, was characterised by heightened network management when the success of the proposal for the Community Housing Fund led to a proliferation of new governance arrangements summarised in Fig. 3.

The three sub-field umbrellas for co-operatives $(\mathrm{CCH})$, community land trusts (NCLTN) and co-housing organisations (UKCN) were joined by Locality (a more general umbrella for development trusts) to organise a range of infrastructure support for local groups across the country to

\footnotetext{
2 http://www.nationwidefoundation.org.uk/projects-we-fund/fund ing-2013-16/building-and-social-housing-foundation-bshf/.
} 
Fig. 3 Emerging network management structure to deliver Community Housing Fund (as of 2019). Source: CommunityLed Homes Steering Group Presentation February 2019

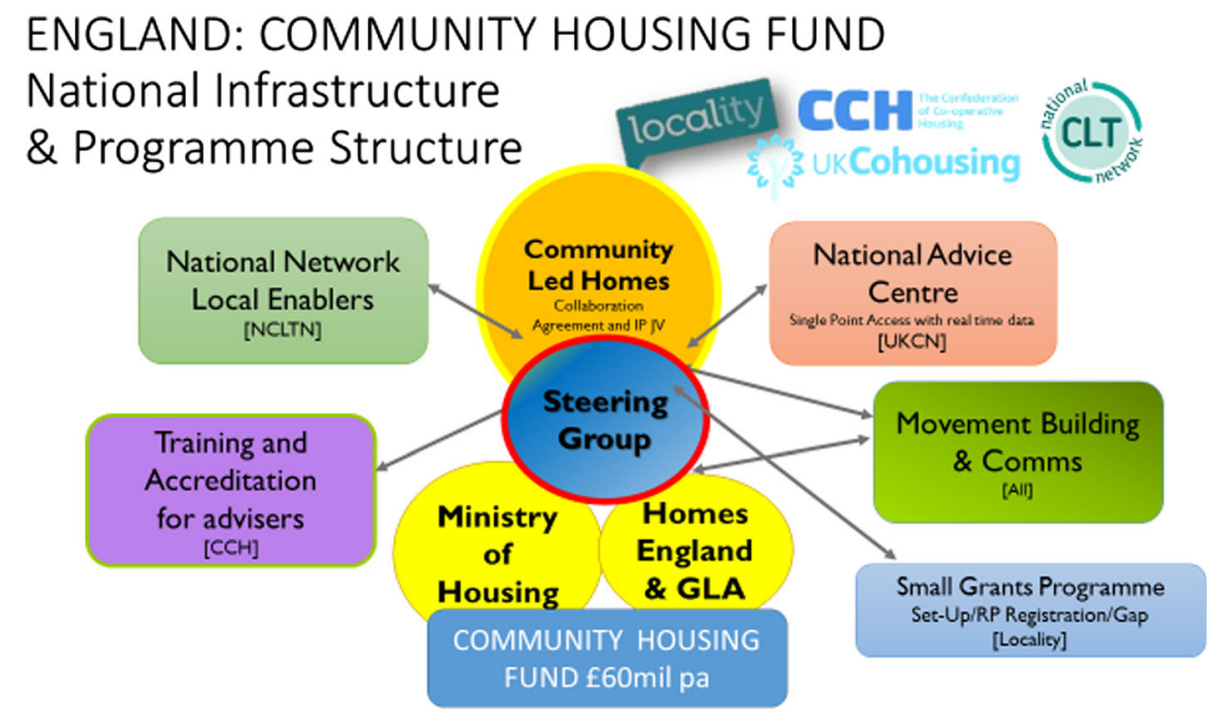

secure support from the Community Housing Fund and develop local projects. As Fig. 3 shows, these four umbrella bodies were joined by governmental actors who sponsored and administered the Community Housing Fund - the Ministry of Housing (MHCLG), and Homes England and Greater London Authority. Other actors actively engaged in the network now included Power to Change (a community business fund resourced by the Big Lottery) who provided funds for individual CLH groups and part of the network of regional enabling hubs in a similar way to Nationwide Foundation. These external resource and regulatory actors were the key to activation of the network to resource local projects and a national network of enabler hubs. Interestingly, in relation to network management theory, the roles of existing actors were redefined as they began to work together in new ways on new roles. While they continued to maintain their historic affiliations with their sub-fields, the new roles were functional and cut across the existing boundaries.

To sum up, in the case of CLH, there is still no single legal or regulatory regime across the field to parallel that of "registered housing providers" found in mainstream social housing. However, drawing on the network management literature, we can see a gradual process of field strengthening through covenanting, reframing and network constitution and activation. Thus, there is now a growing case for CLH to be considered a field as it reflects a substantial level of awareness emerging among a set of civil society actors for shared principles and aspirations underlying their individual housing models. With the implementation of the Community Housing Fund, there has been more formalised collaboration between the national umbrellas to take responsibility for different aspects of field building (see Fig. 3), such as training and accreditation $(\mathrm{CCH})$, a common website platform as single point access (UKCN), support for regional and local enabler hubs (NCLTN) and small grants programme (Locality) as outlined by key players at the "Hope for Housing Conference" in July 2018 (HCRG 2018). However, these field-building activities are carried out in a complex matrix to preserve the sub-field identities (as shown in Fig. 3). The limited time period over which the Community Housing Fund is currently available (to 2020) also means that it is too early to assess any lasting impact on longer term field building.

\section{Discussion of Results}

The results presented in the previous section suggest that the application of elements from different field theories has been useful in structuring the empirical account of CLH in England. In this section, we will first discuss key empirical results and put them in an international context. Then, we will focus on theoretical implications of our study, especially in terms of field structuration which we believe has potential to inform field analysis in civil society studies more generally. 
In the external environment, political and legislative changes have previously been observed as triggers for the formation of non-profit housing fields. In Austria, for instance, the Green Party entered a coalition local government in Vienna in 2010 which triggered legislation for direct access to land and public funding for community self-build groups (Baugruppen) (Lang and Stoeger 2018). While the Localism Bill in 2010 and related Big Society agenda created a positive discursive environment for $\mathrm{CLH}$ in England, our data suggest that longer term structural factors are linked to the emergence of CLH as a field. Particularly, state retreat from direct housing provision eventually led to a redrawing of boundaries and fragmentation in the field of non-profit housing associations but also with private rental market housing. This has created an important space for the emergence of new civil society organisations, similar to the external drivers observed for new tenant co-operatives in Continental Europe (Brandsen and Helderman 2012; Suter and Gmür 2018).

In the early period of the study, we found less evidence of successful social skill in institutionalising CLH at field level but identified several examples in specific niches (self-help housing and CLTs). These framing practices to build actor coalitions focused on particular places where short-term successes were achieved in accessing state resources by connecting micro-level goals with macrolevel political discourses. Examples include self-help housing connected to the "localism" and "big society" political discourses, and CLTs with the crisis of rural housing affordability and second home ownership. Similar successful local framing practices have been identified in Hamburg and Gothenburg (Scheller and Thörn 2018) and Vienna (Lang and Stoeger 2018) where community selfbuild housing practice is linked to political discourses of urban sustainable development. Nevertheless, these recent examples of civil society housing movements, including CLH in England, still operate within a "cognitively accepted neoliberal macro-paradigm" that remains intact (Nicholls and Teasdale 2017, p. 338). In the latter period of the study, we found greater evidence of field legitimacy at the national level particularly through the Community Housing Fund and associated charitable foundation programmes.

In terms of field autonomy, Fligstein and McAdam's (2011, p. 3) notion of "Russian dolls" helps to conceptualise CLH as a particular meso-level social order overlapping with larger and smaller fields at the same time (Barman 2016). Thus, co-operative housing, for instance, is embedded in the larger field of CLH and social housing, and these fields are in turn affected by the market field. CLH is also linked to the field of non-profit housing associations. The process of engagement with the state field has always been important in the search for legitimacy and funding for key actors in CLH. But even where this has been successful, it appears to have been rather temporary. The lack of continued state support after 1980 is a reason why co-operatives in England have never developed into a mainstream form of housing delivery as in some other European countries like Sweden or Norway (Sørvoll and Bengtsson 2018). Similarly, if the Community Housing Fund is not extended after 2020, the period described in this paper might prove to be another short-term engagement with the state, and a similar outcome is likely for CLH.

Turning to some important theoretical implications of our study, we find the structure of the CLH field characterised by small organisations and movements with limited resources available which makes it difficult for them to occupy a dominant position within the field. One has to keep in mind that the whole CLH field is rather small, only occupying a share of about $1 \%$ of the total English housing market (Heywood 2016). Therefore, the struggles for economic resources are not really contested within the CLH field but in adjacent fields. Against this backdrop, we would interpret the genuine effort among socially skilled actors to introduce cooperation rather than competition in the field of CLH. There are clearly established actors in the CLH field with their own identifiable governance units, especially housing co-operatives, but there has also been a substantial level of start-ups in other sub-fields, notably CLTs including for the first time in urban areas (Moore et al. 2018). However, it does not seem to be the case that the rules of the game are stacked in favour of the former. While longer established, the co-operative sector remains fragmented and mainly focused on existing projects and this has limited its ability to align and influence newer CLH start-ups such as CLTs. With Gorski (2012, p. 333), we could thus characterise the structure of the CLH field as a "big box" with "low degrees of both hierarchy and orthodoxy but strong horizontal ties based on permeable organisations and overlapping networks". This field type is more characteristic of grass-roots social movements than 
established non-profit fields where we often find competing power centres of orthodoxy.

Despite visioning, communication and promotion work around the project of a core governance unit, a clear internal and external identity of the field had been missing before the Community Housing Fund galvanised a degree of co-ordinated action, with cross-field umbrellas at the local and regional level (HCRG 2018). Nevertheless, competing conceptions of purpose and a plethora of organisational models remain, reflecting the lengthy history of institutionalisation at the micro-level. Despite growing recognition and legitimacy, the CLH field is still not widely known to the public and has a relatively small cadre of supporters and enablers in the key professional areas needed for stable field growth such as housing financiers, architects, property professionals as well as governmental funders and regulators.

The relatively weak institutionalisation of the CLH field is partly a result of its actors remaining anchored in their original fields. Although we have shown that key players in the CLH field consider each other relevant, their roles and positions are primarily structured by the rules and resources of neighbouring fields. Given its permeable borders with different neighbouring fields, CLH has some affinities with the concept of an "interstitial field" (Medvetz 2012). Such an "in-between field" might appear "weak" and incomplete in terms of internal structure, but its purpose is to provide space for strategic multipositioning of actors as well as facilitating exchange of ideas and pooling of resources across traditional institutional boundaries. We believe that such a strategic perspective on organisational fields can help in shedding more light on collective action in other parts of the civil society, such as recent urban mobilisation in various countries (Domaradzka 2018).

\section{Conclusions}

Based on engagement with different streams of field and network governance literature, the paper explored the factors influencing the recent re-emergence of organised collective action around the theme of collaborative housing. The empirical study focused on CLH as an emerging collaborative housing field within the English housing and civil society context.

The re-emergence of collective action around the theme of collaborative housing makes sense if we look at it in relation to its boundaries with a number of adjacent fields. Conventionally, housing fields are seen as being organised by tenure with quite distinct sets of actors, governance units and interactions in the home ownership, private rental and social rental fields. However, these boundaries have more recently been eroded by state policies that have undermined the distinctiveness of social housing and promoted private rental provision for low-income groups. These developments created opportunities for a new strategic organisational space in civil society.

As a response, like-minded established and new civil society organisations have built temporary coalitions to claim distinctiveness from actors in adjacent fields and framed a nested organisational space as community-led housing (CLH) in England. They hope to escape isomorphic pressures and to maintain distinct identities from dominant actors and organisational models but basically, they remain very interwoven with neighbouring fields from where they secure resources and gain legitimacy. This phenomenon has been observed with voluntary and grassroots movements in other sectors and countries too (Lune and Martinez 1999; Macmillan 2013; Diani et al. 2018).

The analysis in this paper provides further insights on the relative autonomy and institutionalisation of civil society fields. The shared awareness of macro-level societal problems, such as a dysfunctional housing system, among like-minded social movements is a key driver behind collective action and field formation. However, the results of this study suggest that collective action is not necessarily a unified response, but we find sets of civil society actors who are driven by regionally based agendas and governance units. Thus, in our case of the CLH field in England, we do not find much scaling and institutional completeness, i.e. regulators, funders, consultants, etc. working fairly exclusively within the field and providing it with economic resources.

Considering the dimension of scale in the field analysis makes the fragmentation of CLH even more visible and strengthens its character as a social movement field (Domaradzka 2018). The spatial perspective also highlights the limited but growing institutionalisation of $\mathrm{CLH}$ on the national level, in contrast to the non-profit housing associations field. Evidence from other countries actually suggests that the institutionalisation of collaborative housing fields is more likely to happen on the local than on the national level (Lang and Stoeger 2018; Scheller and Thörn 2018). Thus, future studies should emphasise the spatial 
dimension in the analysis of field emergence (e.g. by exploring emergence conditions for regional enable$r$ hubs) and also compare factors leading to successful and failed institutionalisation of civil society fields in different countries.

However, our study also suggests that the purpose of a weakly structured field with permeable borders can simply be to facilitate the strategic positioning of civil society actors in multiple adjacent fields. Such an "interstitial field" (Medvetz 2012) represents an important cross-sectoral space and provides its participants with a hybrid identity.

In conclusion, we concur with Nicholls and Teasdale's (2017) focus on the nested nature of policy paradigms that drive and constrain the institutionalisation process of a field. Despite examples of socially skilled action at the micro-level of CLH, there has been relatively little change in the ways in which housing policy in England is conceived and operated on the macro-level. In the early part of our study (2010-2014), CLH actors had achieved connections with some policy streams (notably "Localism") and some resource allocation and policy processes (notably EHCGP) and modelled different ways of doing things. These connections gradually led to a strategic project to build a more unified CLH field which was partially successful in securing field-wide resources, especially the Community Housing Fund. Since 2018, there is evidence of enhanced collaboration across the field. However, given that the third stage of heightened network management can largely be related to the external stimulus of the Community Housing Fund which currently ends in 2020, it seems too early to conclude whether there will be a long-term movement to a more unified field.

Acknowledgements Open access funding provided by Johannes Kepler University Linz. We would like to acknowledge with gratitude the input and effort contributed by participants in the community-led housing field in England who engaged in various ways with this study and shared their insights and experiences with us. The authors would also like to thank Rob Macmillan for his helpful comments on an earlier version of the paper.

Funding Richard Lang's contribution was funded by an APARTfellowship of the Austrian Academy of Sciences (Grant Number 11696) and FP7 People Marie-Curie Action (Grant Number 622728).

\section{Compliance with Ethical Standards}

Conflict of interest The authors declare that they have no material conflicts of interest. The involvement of one author in the development of a regional enabler hub and as a trustee of UK Cohousing Trust after the main fieldwork period is declared.

Open Access This article is distributed under the terms of the Creative Commons Attribution 4.0 International License (http://crea tivecommons.org/licenses/by/4.0/), which permits unrestricted use, distribution, and reproduction in any medium, provided you give appropriate credit to the original author(s) and the source, provide a link to the Creative Commons license, and indicate if changes were made.

\section{Appendix}

See Tables 2 and 3.

Table 2 Overview of key interview sources

\begin{tabular}{ll}
\hline Role of interviewee & $\begin{array}{l}\text { Date of } \\
\text { interview }\end{array}$ \\
\hline $\begin{array}{l}\text { Executive of Confederation of Co-operative Housing } \\
\text { (CCH) }\end{array}$ & $30 / 04 / 2013$ \\
Community-led housing consultant and former & $08 / 05 / 2013$ \\
$\quad$ director of housing co-operative in Birmingham & \\
Executive of National Community Land Trust & $10 / 05 / 2013$ \\
$\quad$ Network (NCLTN) & \\
Executive of Self-help Housing Network (SHHO) & $10 / 05 / 2013$ \\
Executive of UK Cohousing Network (UKCN) & $11 / 06 / 2013$ \\
Director of housing co-operative in Redditch & $24 / 06 / 2013$ \\
Executive of self-help housing organisation in & $29 / 04 / 2016$ \\
$\quad$ Middlesbrough & \\
Board member of community land trust in Liverpool & $23 / 08 / 2016$ \\
Executive of co-operative housing provider in & $23 / 08 / 2016$ \\
$\quad$ Liverpool & \\
Representative of local council in Liverpool & $23 / 08 / 2016$ \\
Board member of community development charity & $04 / 10 / 2016$ \\
$\quad$ and community land trust in London & \\
Representative of local council in Redditch & $14 / 12 / 2016$ \\
\hline
\end{tabular}


Table 3 Overview of key participatory observations 2014-2016

Participatory observations at CLH field level

\begin{tabular}{llc}
\hline Observation purpose & Location of field visit & Date of field visit \\
\hline BSHF consultation "Scaling-up community housing solutions" & Windsor, UK & $28 / 05 / 2014$ \\
HACT Community-led housing event & London, UK & $28 / 01 / 2015$ \\
Self-help housing conference "The Impact of the Empty Homes Community Grants Programme” & Hull, UK & $26 / 02 / 2015$ \\
BSHF consultation "Strategic Alliance" & Birmingham, UK & $28 / 05 / 2015$ \\
UK Co-housing Network (UKCN) seminar "Collaborative Housing and Community Resilience” & Lancaster, UK & $26 / 06 / 2015$ \\
Meeting of the Mutual Housing Group (MHG) & London, UK & $03 / 02 / 2016$ \\
Annual Conference of the Confederation of Co-operative Housing $(\mathrm{CCH})$ & Loughborough, UK & $13 / 05 / 2016$ \\
Conference "Future of Social Housing" & Birmingham, UK & $03 / 06 / 2016$
\end{tabular}

Authors were also present at the first national Community-Led Housing Conference (November 2017); Hope for Housing Conference, Birmingham (July 2018); Community-Led Housing Gathering, Leeds (June 2019); monthly steering group meetings of Birmingham Community Homes (April 2018-July 2019); and UK Cohousing Trustees meetings from February 2019

\section{References}

Ahrne, G., \& Brunsson, N. (2011). Organization outside organizations: The significance of partial organization. Organization, 18(1), 83-104.

Armstrong, E. (2005). From struggle to settlement: The crystallization of a field of lesbian/gay organizations in San Francisco, 1969-1973. In G. Davis, D. McAdam, W. R. Scott, \& M. N. Zald (Eds.), Social movements and organization theory (pp. 161-187). Cambridge: Cambridge University Press.

Barman, E. (2016). Varieties of field theory and the sociology of the non-profit sector. Sociology Compass, 10(6), 442-458.

Benson, R. (2006). News media as a "Journalistic Field": What Bourdieu adds to new institutionalism, and vice versa. Political Communication, 23(2), 187-202.

Birchall, J. (1992). Housing co-operatives in Britain, Department of Government Working Papers No. 21, London: Brunel University.

Bourdieu, P. (1990). The logic of practice. Cambridge: Polity Press.

Bourdieu, P. (1991). Genesis and structure of the religious field. Comparative Social Research, 13, 1-44.

Bourdieu, P. (1995). The rules of art: Genesis and structure of the literary field. Stanford, CA: Stanford University Press.

Bourdieu, P., \& Wacquant, L. J. D. (1992). An invitation to reflexive sociology. Chicago: University of Chicago Press.

Brandsen, T., \& Helderman, J.-K. (2012). The trade-off between capital and community: The conditions for successful coproduction in housing. VOLUNTAS: International Journal of Voluntary and Nonprofit Organizations, 23(4), 1139-1155.

BSHF (Building and Social Housing Foundation). (2014a). Сотmиnity-led housing making it happen. Coalville: BSHF.

BSHF (Building and Social Housing Foundation). (2014b). Scaling up community housing solutions. Coalville: BSHF.

CCMH (Commission on Co-operative and Mutual Housing). (2009). Bringing democracy home. Report of the Commission on Cooperative and Mutual Housing. http://www.cch.coop/wp-con tent/uploads/2015/07/bdh-commission-report.pdf. Accessed 17 Nov 2018.

Chalaby, J. K. (1998). The invention of journalism. Basingstoke: Macmillan.
Cohen, M. D., March, J. G., \& Olsen, J. P. (1972). A garbage can model of organizational choice. Administrative Science Quarterly, 17(1), 1-25.

Davis, J. E. (2002). Narrative and social movements. In J. E. Davis (Ed.), Stories of change: Narrative and social movements (pp. 3-29). Albany, NY: SUNY Press.

Diani, M., Ernstson, H., \& Jasny, L. (2018). "Right to the City" and the structure of civic organizational fields: Evidence from Cape Town. VOLUNTAS: International Journal of Voluntary and Nonprofit Organizations, 29(4), 637-652.

DiMaggio, P. J., \& Powell, W. W. (1983). The iron cage revisited: Institutional isomorphism and collective rationality in organizational fields. American Sociological Review, 48(2), 147-160.

Domaradzka, A. (2018). Urban social movements and the right to the city: An introduction to the special issue on urban mobilization. VOLUNTAS: International Journal of Voluntary and Nonprofit Organizations, 29(4), 607-620.

Domaradzka, A., \& Wijkström, F. (2016). Game of the city renegotiated: The Polish urban re-generation movement as an emerging actor of a strategic action field. Polish Sociological Review, 195(3), 291-308.

Emirbayer, M., \& Johnson, V. (2008). Bourdieu and organizational analysis. Theory and Society, 37(1), 1-44.

Ferguson, P. (1998). A cultural field in the making: Gastronomy in nineteenth century France. American Journal of Sociology, 104(1), 597-641.

Finnemore, M., \& Sikkink, K. (1998). International norm dynamics and political change. International Organization, 52(4), 887-917.

Fligstein, N., \& McAdam, D. (2011). Toward a general theory of strategic action fields. Sociological Theory, 29(1), 1-26.

Fligstein, N., \& McAdam, D. (2012). A theory of fields. London: Oxford University Press.

Florea, I., Gagyi, A., \& Jacobsson, K. (2018). A field of contention: Evidence from housing struggles in bucharest and budapest. VOLUNTAS: International Journal of Voluntary and Nonprofit Organizations, 29(4), 712-724.

Fromm, D. (2012). Seeding community: Collaborative housing as a strategy for social and neighbourhood repair. Built Environment, 38(3), 364-394.

Fuchs, S. (2014). How not to do (field) theory. Contemporary Sociology: A Journal of Reviews, 43(3), 312-314 
Gamson, W. (1975). The strategy of social protest. Homewood, IL: Irwin Press.

Gorski, P. S. (2012). Bourdieusian theory and historical analysis: Maps, mechanisms, and methods. In P. S. Gorski (Ed.), Bourdieu and historical analysis (pp. 327-367). Chapel Hill: Duke University Press.

Guthrie, D., \& McQuarrie, M. (2008). Providing for the public good: Corporate-community relations in the era of the receding welfare state. City and Community, 7(2), 113-139.

HCA (The Homes and Communities Agency). (2011). Communityled development: Eligibility criteria. London: HCA. https:// assets.publishing.service.gov.uk/government/uploads/system/ uploads/attachment_data/file/394037/community_led_eligibility. pdf. Accessed 23 Nov 2018.

HCRG (Housing and Communities Research Group). (2018) Hope for housing conference report. University of Birmingham. https:// www.birmingham.ac.uk/Documents/college-social-sciences/ social-policy/HCRN/hope-for-housing-conference/hrc-report06-11-18.pdf. Accessed 17 Nov 2018

Heywood, A. (2016). Local housing, community living: Prospects for scaling up and scaling out community-led housing. London: The Smith Institute.

Homes England (2018). Community housing fund prospectus. https:// assets.publishing.service.gov.uk/government/uploads/system/ uploads/attachment_data/file/721611/CHF_prospectus_-FINAL.pdf. Accessed November 17, 2018.

Howard, E. (1898). Tomorrow. A peaceful path to social reform. London: Swann Sonnerschein.

Huber, A. (2017). Theorising the dynamics of collaborative consumption practices: A comparison of peer-to-peer accommodation and cohousing. Environmental Innovation and Societal Transitions, 23, 53-69.

ICA (International Co-operative Alliance). (2015). Guidance notes to the co-operative principles. http://www.ica-ap.coop/sites/ica-ap. coop/files/Guidance\%20Notes\%20EN.pdf. Accessed 17 July 2019.

id22: Institute for Creative Sustainability (ed.) (2012). CoHousing cultures: Handbook for selforganized, community-oriented and sustainable living. Berlin: Jovis Publishing.

Jezierska, K., \& Polanska, D. V. (2017). Social movements seen as radical political actors: The case of the Polish Tenants' movement. VOLUNTAS: International Journal of Voluntary and Nonprofit Organizations, 29(4), 683-696.

Jones, A. (2017). Housing choices in later life as unclaimed forms of housing activism. Contemporary Social Science, 12(1-2), $138-152$.

Kehl, K., \& Then, V. (2013). Community and civil society returns of multi-generation cohousing in Germany. Journal of Civil Society, 9(1), 41-57.

Klijn, E.-H., \& Teisman, G. R. (1997). Strategies in games and networks. In W. J. M. Kickert, E.-H. Klijn, \& J. F. P. Koppenjan (Eds.), Managing complex networks (pp. 98-118). London: Sage.

Koppenjan, J. F. M., \& Klijn, E. H. (2004). Managing uncertainties in networks: A network approach to problem solving and decision making. London: Routledge.

Krause, M. (2018). How fields vary. British Journal of Sociology, 69(1), 3-22.

Lang, R., Carriou, C., \& Czischke. D. (2018). Collaborative housing research (1990-2017): A systematic review and thematic analysis of the field. Housing, Theory and Society, 1-30. https://doi.org/10.1080/14036096.2018.1536077.

Lang, R., \& Stoeger, H. (2018). The role of the local institutional context in understanding collaborative housing models: Empirical evidence from Austria. International Journal of Housing Policy, 18(1), 35-54.
Lune, H., \& Martinez, M. (1999). Old structures, new relations: How community development credit unions define organizational boundaries. Sociological Forum, 14(4), 609-634.

Macmillan, R. (2013). 'Distinction' in the third sector. Voluntary Sector Review, 4(1), 39-54.

Macmillan, R., Taylor, R., Arvidson, M., Soteri-Proctor, A., \& Teasdale, S. (2013). The third sector in unsettled times: A field guide. Third Sector Research Centre Working Paper 109, University of Birmingham.

Marsh, D., \& Rhodes, R. A. W. (1992). Policy networks in British government. New York: Oxford University Press.

Mayring, P. (2010). Qualitative content analysis basics and techniques. (Qualitative Inhaltsanalyse. Grundlagen und Techniken) (11th ed.). Weinheim: Beltz.

McInerney, P.-B. (2015). Walking a fine line: How organizations respond to the institutional pluralism of intersectoral collaboration. Social Currents, 2(3), 280-301.

McQuarrie, M., \& Krumholz, N. (2011). Institutionalized social skill and the rise of mediating organizations in urban governance: The case of the Cleveland Housing Network. Housing Policy Debate, 21(3), 421-442.

Medvetz, T. (2012). Think tanks in America. Chicago: University of Chicago Press.

Moore, T., Mullins, D., He, B., Thompson, M., Claasen, C., \& Archer, T. (2018). The urban CLT project evaluation. National Community Land Trust Network. http://www.communitylandtrusts. org.uk/_filecache/f28/204/635-final-ucltp-report.pdf. Accessed November 17, 2018

Mullins, D. (2016). The changing role of housing associations. In J. Rees \& D. Mullins (Eds.), The third sector delivering public services: Developments, innovations and challenges ( $\mathrm{pp}$. 211-232). Oxford: Policy Press.

Mullins, D. (2018). Achieving policy recognition for communitybased housing solutions: The case of self-help housing in England. International Journal of Housing Policy, 18(1), 143-155.

Mullins, D., \& Moore, T. (2018). Self-organised and civil society participation in housing provision. International Journal of Housing Policy, 18(1), 1-14.

Mullins, D., Rhodes, M. L., \& Williamson, A. (2001). Organizational fields and third sector housing in Ireland, North and South. VOLUNTAS: International Journal of Voluntary and Nonprofit Organizations, 12(3), 257-278.

Mullins, D., \& Riseborough, M. (1997). Changing with the times: Critical interpretations of the repositioning of housing associations, School of Public Policy Occasional Paper 12, University of Birmingham.

Murie, A. (2008). Moving homes: The housing corporation 1964-2008. London: Poltico's.

NCLTN (National CLT Network). (2014). Our homes our communities: A manifesto for community land trusts. London: National CLT Network.

Nicholls, A. (2010a). The legitimacy of social entrepreneurship: Reflexive isomorphism in a pre-paradigmatic field. Entrepreneurship theory and practice, 34(4), 611-633.

Nicholls, A. (2010b). Institutionalizing social entrepreneurship in regulatory space: Reporting and disclosure by community interest companies. Accounting, Organizations and Society, 35(4), 394-415.

Nicholls, A., \& Teasdale, S. (2017). Neoliberalism by stealth? Exploring continuity and change within the UK social enterprise policy paradigm. Policy and Politics, 45(3), 323-341.

Ostrom, V. (1980). Hobbes, covenant and constitution. Publius, 10(4), 83-100.

Pettinicchio, D. (2013). Strategic action fields and the context of political entrepreneurship: How disability rights became part of 
the policy agenda. Research in Social Movements, Conflicts and Change, 36, 79-106.

Purkis, A. (2010). Housing associations in England and the future of voluntary organisations. London: The Baring Foundation.

Rowlands, R. (2009). Forging mutual futures-co-operative, mutual and community based housing in practice: History and potential. Birmingham: Commission on Co-operative \& Mutual Housing.

Ruiu, M. L. (2014). Differences between cohousing and gated communities. A literature review. Sociological Inquiry, 84(2), 316-335.

Sayer, A. (1992). Method in social science: A realist approach (2nd ed.). London: Routledge.

Scheller, D., \& Thörn, H. (2018). Governing 'sustainable urban development' through self-build groups and co-housing: The cases of Hamburg and Gothenburg. International Journal of Urban and Regional Research, 42(5), 914-933.

Scott, W. R. (1995). Institutions and organizations. London: Sage.

Scott, W. R., \& Meyer, J. W. (1983). The organization of societal sectors. In J. W. Meyer \& W. R. Scott (Eds.), Organizational environments: Ritual and rationality (pp. 129-153). Beverly Hills, CA: Sage.

Smith, S. R. (2010). Hybridization and nonprofit organisations: The governance challenge. Policy and Society, 29(3), 219-229.
Snow, D. A., \& Benford, R. D. (1992). Master frames and cycles of protest. In A. Morris \& C. Mueller (Eds.), Frontiers of social movement theory (pp. 133-155). New Haven, CT: Yale University Press.

Sørvoll, J., \& Bengtsson, B. (2018). The pyrrhic victory of civil society housing? Co-operative housing in Sweden and Norway. International Journal of Housing Policy, 18(1), 124-142.

Suter, P., \& Gmür, M. (2018). Volunteer engagement in housing cooperatives: Civil society "en miniature". VOLUNTAS: International Journal of Voluntary and Nonprofit Organizations, 29(4), $770-789$.

Swartz, D. L. (2014). Theorizing fields. Theory and Society, 43(6), 675-682.

Van Bortel, G., \& Mullins, D. (2009). Critical perspectives on network governance in urban regeneration, community investment and integration. Journal of Housing and the Built Environment, 24(2), 203-219.

Yin, R. K. (2009). Case study research: Design and methods (4th ed.). Thousand Oaks, CA: Sage.

Publisher's Note Springer Nature remains neutral with regard to jurisdictional claims in published maps and institutional affiliations. 